\title{
Modelli interpretativi per la fruizione digitale delle architetture widinghe
}

\author{
Giulia Lazzari \\ Alessandro Manghi
}

Abstract

Nel corso del XI e XII secolo la Valdisieve cadde sotto il dominio della potente famiglia comitale dei Conti Guidi, già signori del territorio aretino e successivamente anche di quello empolese. Essi avevano compreso appieno l'importanza strategica di questa area, posta sul confine del contado fiorentino, che consentiva loro il controllo sulle mire espansionistiche della ricca borghesia fiorentina [Vannini 2009, p. 208].

La presenza dei Guidi era assicurata dai numerosi castelli, borghi murati ed edifici religiosi sotto il loro diretto controllo o di quello dei loro affiliati. La loro egemonia su queste terre continuò fino al XIV secolo, quando Firenze riprese gradualmente possesso dei territori di frontiera; in questo contesto la Valdisieve, che non rivestiva un particolare interesse per il potere centrale, iniziò un lento declino che investì con particolare inclemenza il patrimonio architettonico [Cherubini 2009, p. 45].

Ad oggi numerose sono le testimonianze di quell'epoca ed è ancora ben leggibile la corona di strutture castellane e pievane erette attorno a Firenze (fig. I).

II contributo intende illustrare i primi esiti di una ricerca che ha per oggetto i manufatti guidinghi eretti nella bassa Valdisieve e come fine quello di realizzare un database contenente i risultati degli studi condotti sugli stessi, a partire da quelli geometrico-dimensionali.

Alle copie digitali di queste strutture, desunte attraverso gli odierni sistemi di rilevamento range based e image based, è stato affidato non solo il compito di documentare il dato morfo-metrico e cromati$\mathrm{co}, \mathrm{ma}$ anche quello di veicolare i frutti delle ricerche stesse in forme nuove e più vicine a quelle che sono le aspettative sia del grande pubblico sia degli addetti ai lavori. (G.L.).

Parole chiave

Ghibertiana, Conti Guidi, rilievo digitale, archeologia, realtà aumentata.

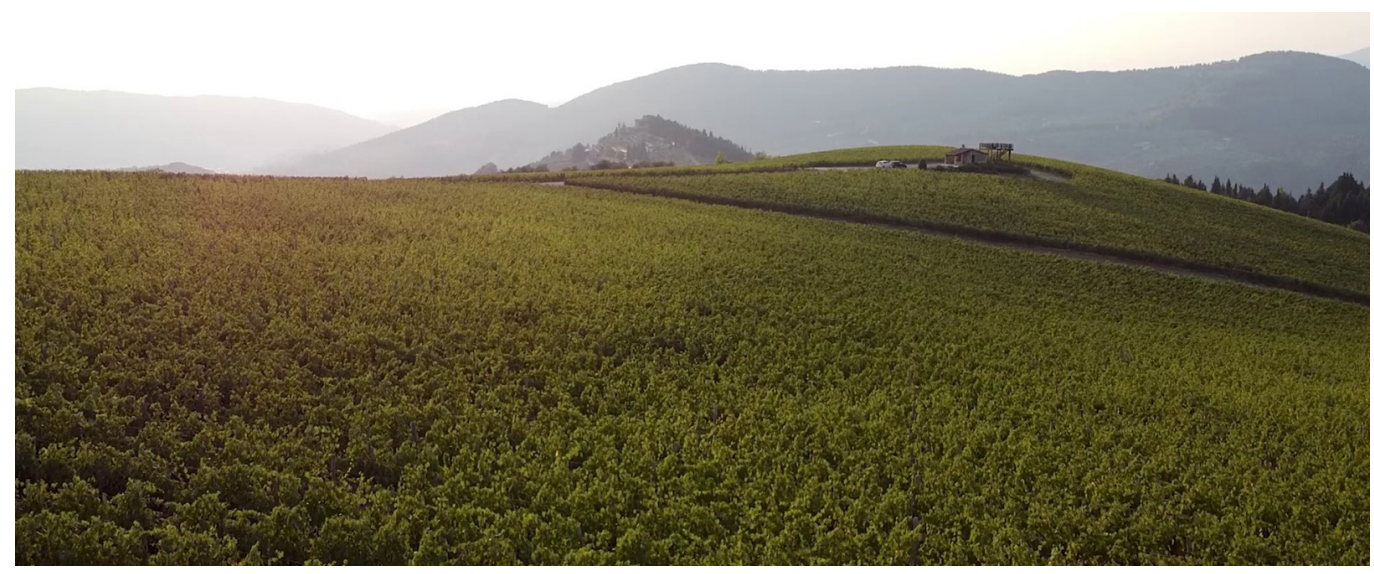




\section{Premessa}

La ricerca oggetto del presente contributo si inserisce all'interno di un progetto complesso, interdisciplinare e multiscalare, denominato 'Ghibertiana' [I], finalizzato alla valorizzazione del legame che vi è tra il patrimonio culturale della bassa Valdsieve [2] e le opere di Lorenzo Ghiberti (Pelago 1378, Firenze 1455), che in questa terra ebbe i natali e investì parte delle sue fortune.

II progetto prevede la realizzazione del Centro di Documentazione su Lorenzo Ghiberti, nel quale saranno raccolte in forma dematerializzata tutte le informazioni relative all'artista e alle sue opere, consentendo agli studiosi di disporre di un luogo dedicato per le ricerche sul maestro, e del Centro di Interpretazione sulla bassa Valdisieve, dove sarà possibile acquisire le chiavi di lettura per decodificare nella corretta prospettiva storica i luoghi di maggior interesse di questa porzione di territorio (Le terre del Ghiberti).

Cinque sono gli assi portanti che qualificano il percorso espositivo di quest'ultimo Centro: il paesaggio della vite e dell'ulivo / i castelli dei conti Guidi / la foresta di Vallombrosa / la lavorazione dei metalli nobili e la bottega del Ghiberti / la porta del Paradiso del battistero di Firenze.

È indubbio che l'immenso patrimonio ereditato dai Conti Guidi, pur nelle trasformazioni avvenute nell'arco di quasi due secoli, caratterizzasse al tempo del Ghiberti così come oggi il paesaggio della bassa Valdisieve.

II rinnovato interesse per queste strutture, talvolta arrivate per lo più integre fino ai nostri giorni, in altri casi documentabili solo attraverso i loro lacerti, ha spinto il gruppo pluridisciplinare - che vede la presenza di storici, storici dell'arte, architetti e archeologi - impegnato

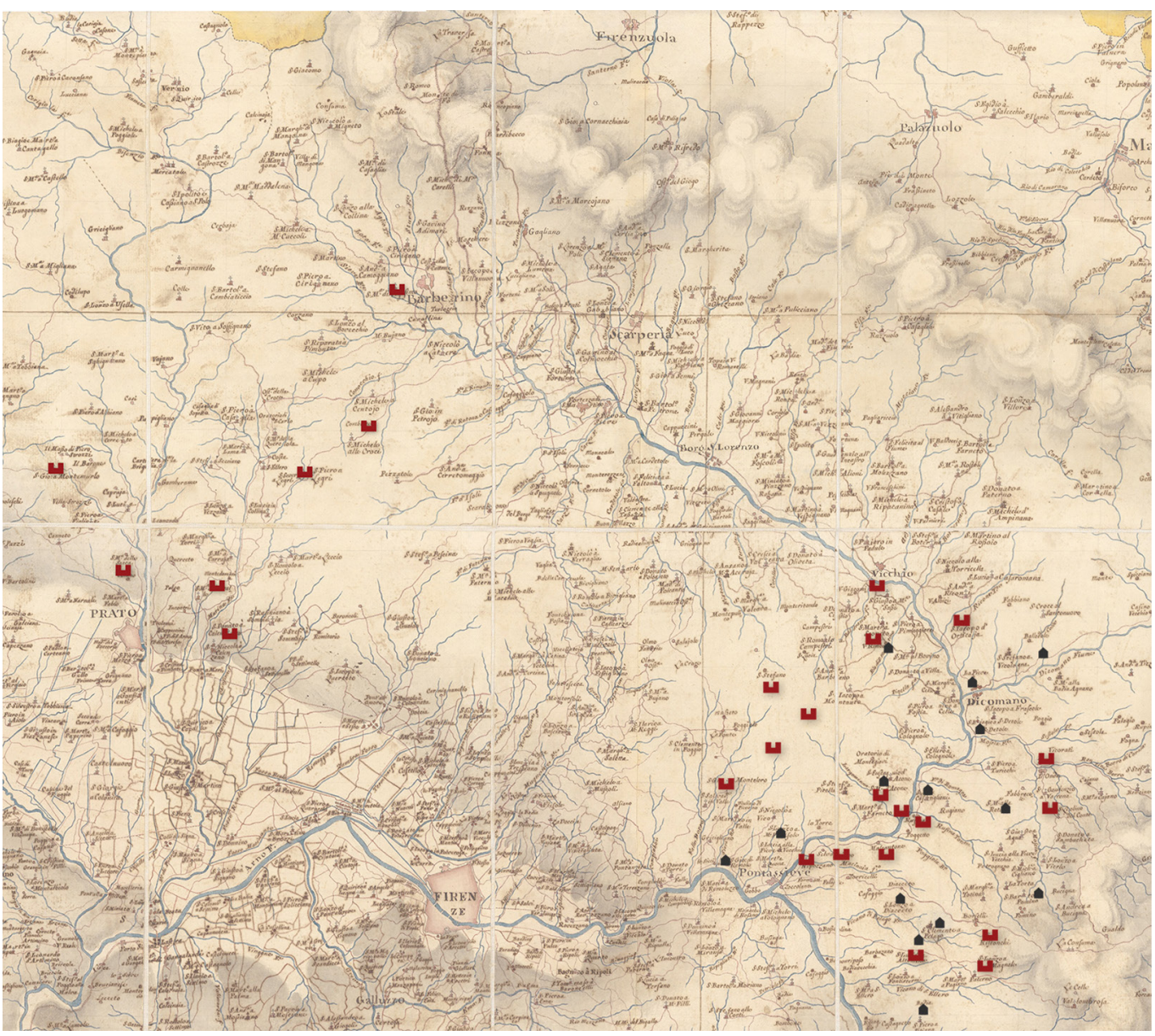


nella ricerca, a individuare nel castello di Nipozzano ed in quello di San Leolino, nella chiesa di Santa Maria a Ferrano, nei resti della pieve di San Gervasio ed in quella di Magnale i manufatti sui quali concentrare i primi studi di carattere storiografico, archeologico e architettonico. (G.L.).

\section{La documentazione morfo-metrica delle architetture widinghe}

Tra le prime operazioni realizzate dal gruppo di lavoro vi sono state quelle finalizzate alla definizione della morfometria dei beni oggetto di indagine.

Questi ultimi sono classificabili in due distinte categorie: la prima comprende gli edifici che versano in uno stato di deprecabile degrado reso ancor più evidente dalla presenza di vegetazione infestante di 'lunga durata' (San Gervasio, San Leolino e porzioni di Nipozzano), ma che conservano numerosi elementi originali (in genere indice di un precoce abbandono); la seconda include quei manufatti che, pur trovandosi in buono stato di conservazione, sono stati oggetto di numerosi interventi di ripristino, tanto da rendere difficilmente individuabili gli elementi ascrivibili al periodo in cui furono eretti (Magnale, Ferrano e numerose fabbriche di Nipozzano).

Come in genere avviene nello studio delle architetture storiche, il rilievo morfo-metrico è chiamato ad ottemperare quanto meno a due scopi: documentare un dato geometrico che si va progressivamente perdendo ed evincere i dati necessari a poter definire i cambiamenti avvenuti nel corso del tempo [Clini 20 I I, p. 9].

Del castello di San Leolino (fig. 2), fortificazione attestabile già al I I 64, rimane un torrione di sezione pressappoco triangolare, con angoli smussati e arrotondati, nel quale si apre un ampio portale, collocato su una parete rocciosa che si erge rispetto al territorio sottostante; persiste ancora in buono stato di conservazione la cisterna collocata nel sottosuolo a cui si accede tramite una scala. II bosco in cui si trova, assieme al collasso di tutte le strutture orizzontali e di buona parte di quelle verticali, nasconde quasi interamente ciò che resta dell'edificio, tanto da avere reso l'acquisizione e la successiva restituzione dei dati particolarmente gravose [3].

II castello di Nipozzano (fig. 3) è senza dubbio uno dei complessi che si mantiene nelle migliori condizioni di conservazione poiché sottoposto nel tempo a numerosi interventi di restauro. L'edificio si erge tra i vigneti delle tenute Frescobaldi, dominando la valle della Sieve con un imponente cassero e due torri minori, ai quali si affianca un piccolo borgo e la chiesa di San Nicolò, risalente al XVI secolo; quest'ultima, come il castello, fu in gran parte ricostruita a seguito dei danni subiti durante la Seconda guerra mondiale. L'area di Nord-Ovest, or-




Fig. 3. Il castello di Nipozzano con in primo piano la chiesa di San Niccolò sulla sinistra e il cassero sulla destra (foto degli autori).

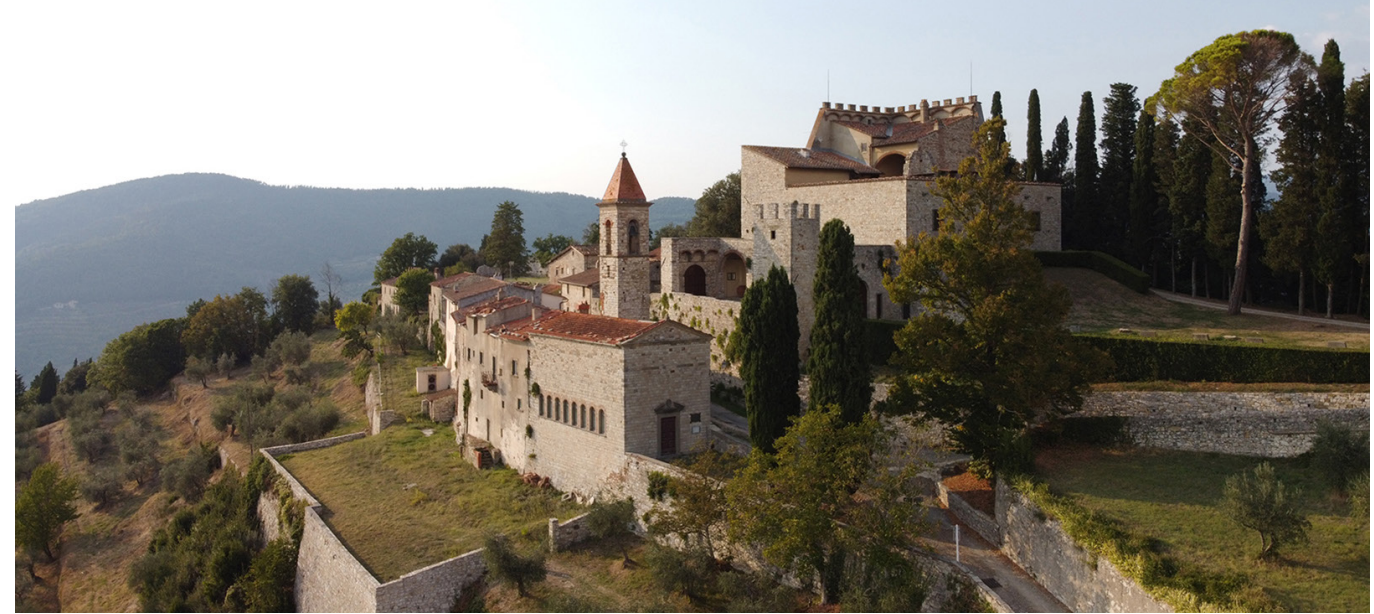

mai allo stato di rudere, presenta alcune porzioni di muratura risalenti all'inizio dell'XI secolo. Ad esclusione di questa zona, per la quale le difficoltà sono simili a quelle riscontrate a San Leolino, le operazioni di rilevamento delle restanti aree non hanno presentato particolari problematiche e sono state condotte sia tramite scanner laser che con fotogrammetria aerea e terrestre [4].

II castellare di Magnale, il cui toponimo denota l'origine etrusca, è nominato negli atti relativi alla vicina Abbazia di Vallombrosa a partire dal I I03. L'aspetto attuale del complesso (fig. 4) è il frutto delle pesanti modifiche avvenute alla metà del Settecento, di cui è possibile individuare l'entità osservando i conci limitrofi al portale d'accesso della chiesa, il fronte laterale sul quale attesta il cimitero e le murature che sorreggono il complesso verso valle. In questo caso il rilievo [5] ha documentato manufatti che vengono ancora utilizzati e il cui stato di manutenzione è da considerare più che buono; ciò ha consentito di ottenere una descrizione morfologica e cromatica completa dei vari fronti e dell'interno della chiesa. Completamente diverso è il caso della pieve di San Gervasio (fig. 5) risalente al I I64; dai pochi resti rimasti è possibile desumere poco più dell'impianto a terra. La vegetazione che ricopre quasi interamente la struttura ha reso oltremodo difficoltose le operazioni di rilevamento [6].

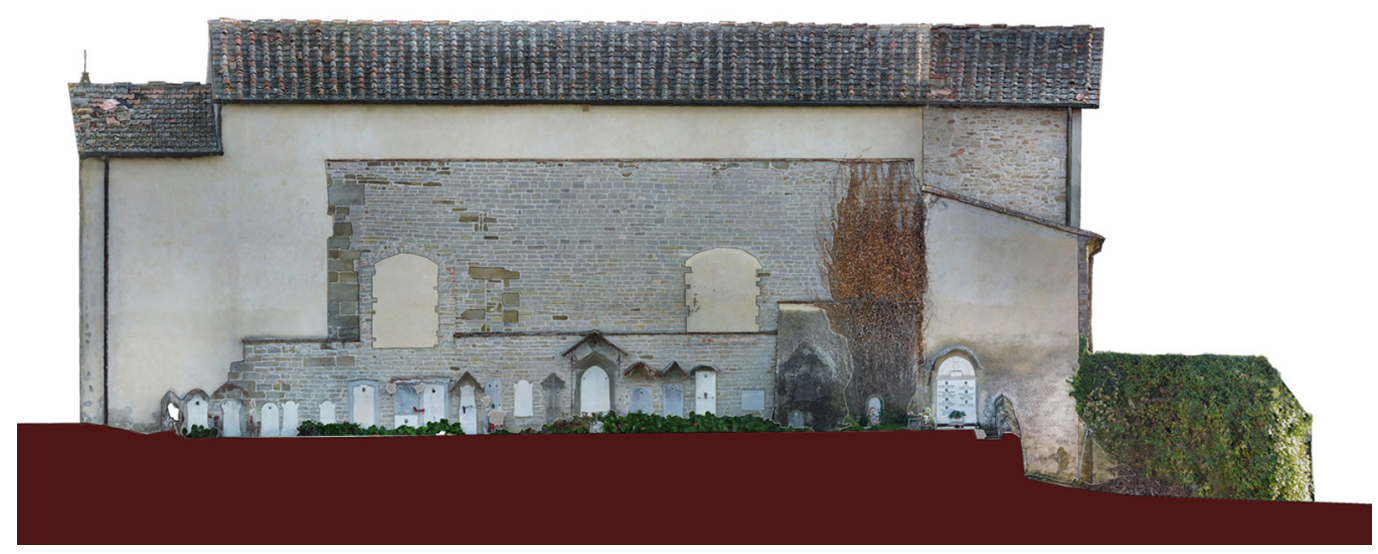

Fig. 4. Prospetto Nord della chiesa di San Niccolò a Magnale (elaborazione degli autori). 
Fig. 5. Resti della pieve di San Gervasio (foto degli autori).

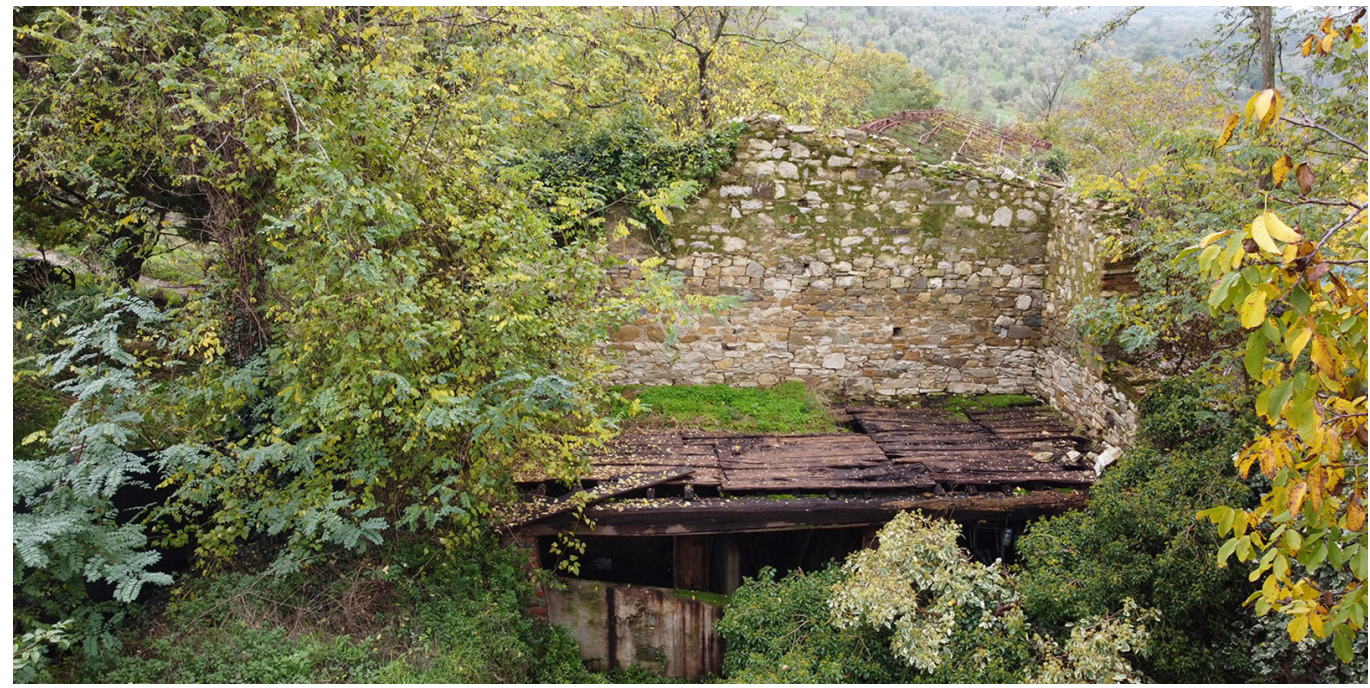

L'ultimo complesso preso in esame è costituito dalla pieve di Santa Maria a Ferrano e dal borgo limitrofo (fig. 6); entrambi sono stati oggetto di restauri anche in tempi molto recenti e si presentano quindi in ottime condizioni. Ad una prima sommaria analisi, la compagine muraria sembra presentare alcuni elementi risalenti all'epoca di costruzione; i dati [7] acquisiti e le successive restituzioni consentiranno di approfondire le prime ipotesi. (A.M.).

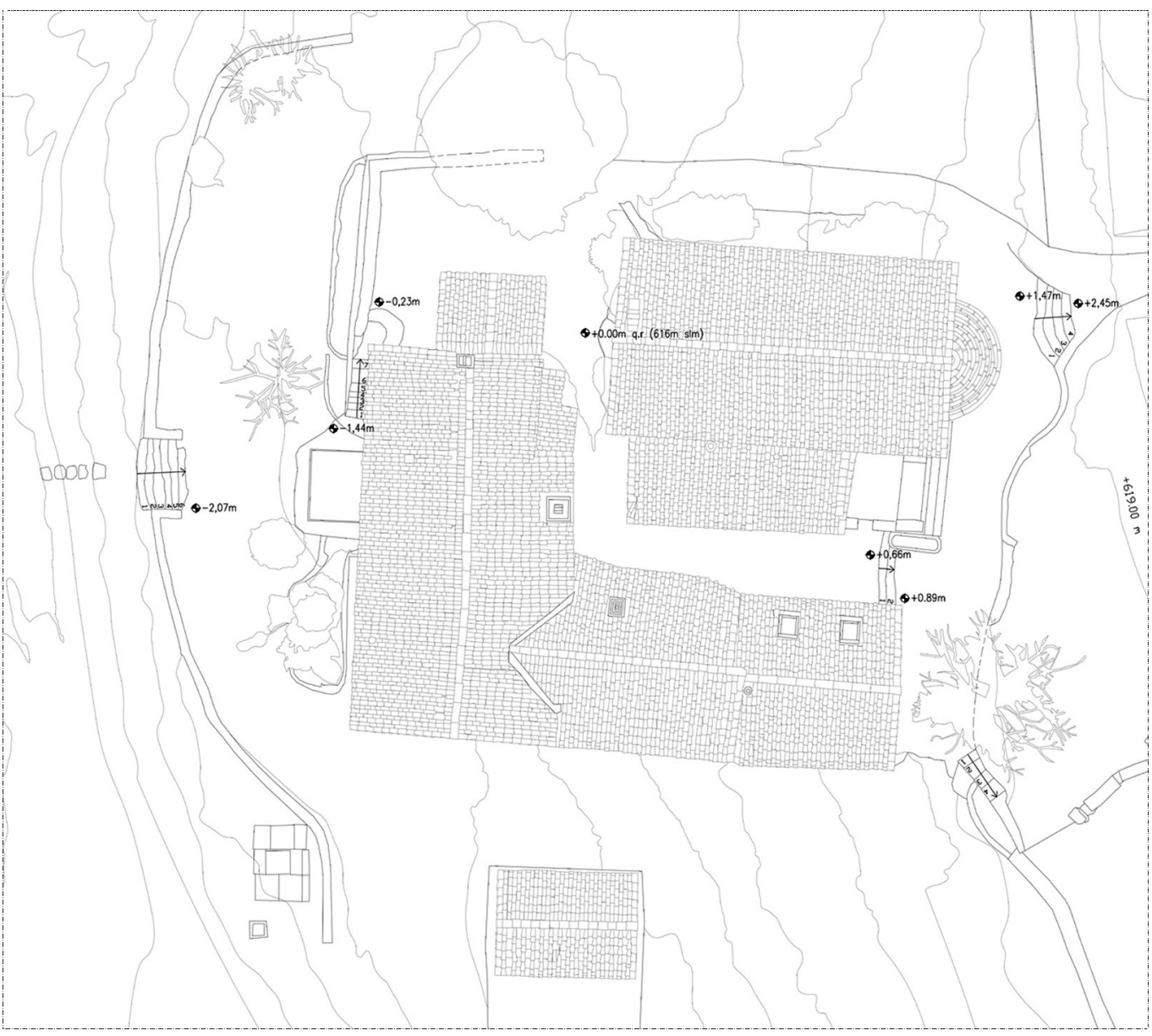
degli autori). 


\section{La lettura del rilievo}

Per quanto nell'epoca delle restituzioni 4.0 i tradizionali elaborati bidimensionali possano risultare obsoleti, è certo invece che piante, sezioni, prospetti e planimetrie, oltre alle ortofoto, rappresentino ancora l'imprescindibile punto di partenza per una lettura approfondita di un manufatto [Bianchini 20|4, pp. I5, I6].

Nella presente ricerca questi ultimi hanno consentito non solo di definire forme, geometrie e dimensioni delle architetture indagate, ma sono risultati indispensabili, ad esempio, per le analisi degli elevati (suddivisione in Unità Stratigrafiche Murarie e riconoscimento dei Corpi di Fabbrica) secondo le indicazioni dell'archeologia leggera [8].

Le murature degli edifici storici sono di fatto un palinsesto nel quale è possibile rintracciare gli interventi di 'costruzione' (ad opera dell'uomo) o di 'distruzione' (sia ad opera dell'uomo che della natura), i quali correttamente interpretati permettono non solo di individuare le mutue relazioni tra le distinte parti di un fabbricato, ma soprattutto di ipotizzare una sequenza cronologica degli eventi che si sono succeduti lungo l'arco dei secoli.

In questo specifico caso il dato cromatico, desunto attraverso le note procedure di fotogrammetria digitale e restituito nei foto-piani, ha reso possibile riconoscere e rappresentare i distinti materiali da costruzione, le tecniche costruttive utilizzate e l'eventuale presenza di decorazioni o di segni lasciati dalle maestranze (fig. 7). (G.L.).

Fig. 7. Uno dei prospetti del borgo che affianca il cassero di Nipozzano (elaborazione degli autori).

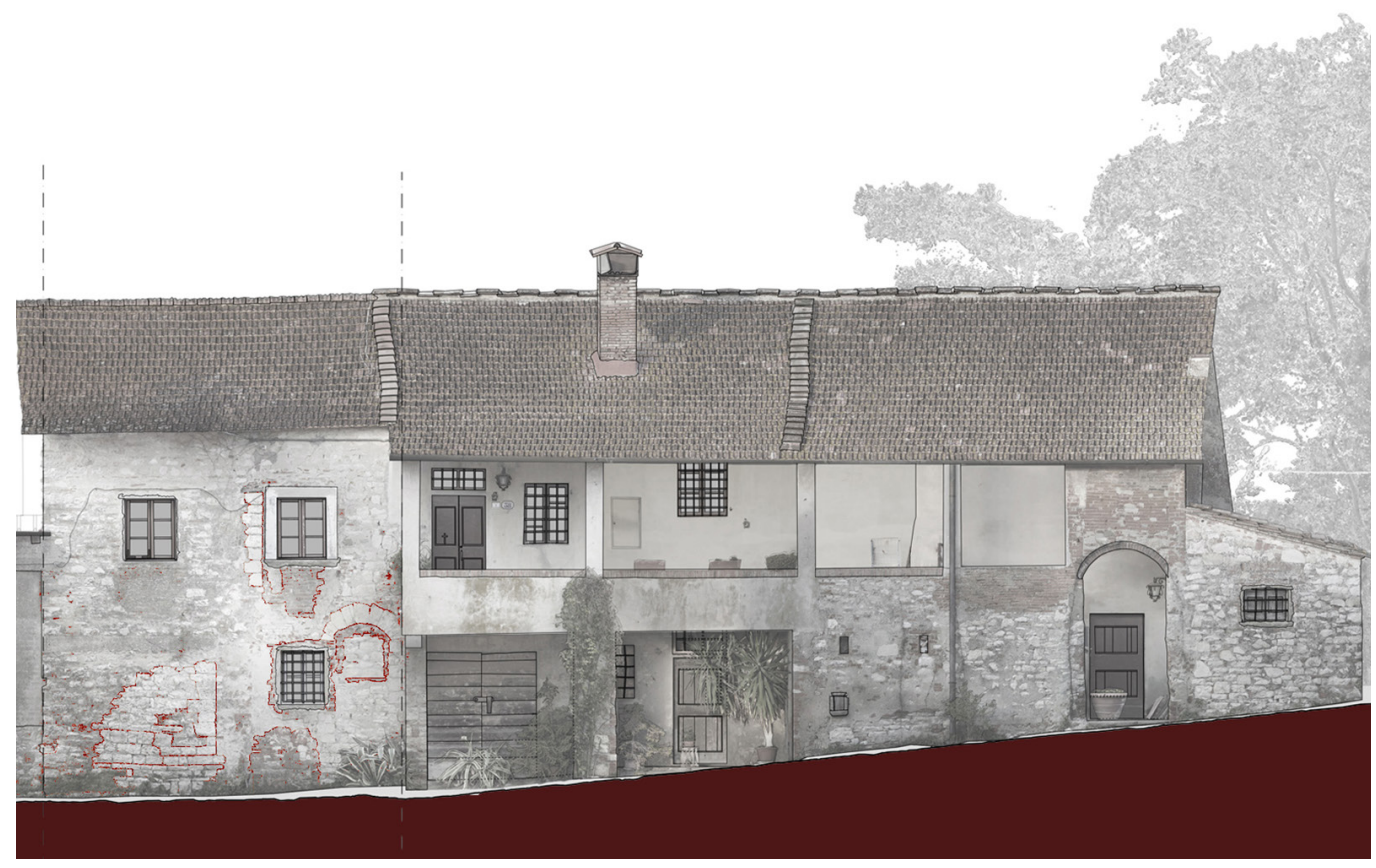

\section{Digital twin e ICT al servizio dell'esperienza museale}

Per gli scopi previsti all'interno del nascente Centro di Interpretazione della bassa Valdisieve, come ad esempio le ricostruzioni 3D delle configurazioni originarie dei manufatti, la realizzazione di stampe tridimensionali oppure la visualizzazione sulle copie digitali delle analisi sugli elevati murari, i modelli mesh estratti dal software Agisoft Metashape sono stati sottoposti a procedure di affinamento e ottimizzazione.

Una volta risolte le problematiche legate alle geometrie delle maglie all'interno del programma 3D Systems Geomagic Design X [9] ogni modello è stato importato nel software Blender $3 \mathrm{D}$ nel quale è stato possibile definire due workflow sulla base delle necessità dell'output finale [Minto 20।3, pp. 7, 8]. 
Fig. 8. Passaggio dalla mesh triangolare non ordinata del modello medium-poly alla mesh quad-dominant del modello low-poly tramite il processo di retopology.

Fig. 9. Schematizzazione del funzionamento dell'App di realtà aumentata sviluppata con Unity e Vuforia.


Nel caso della realizzazione di una stampa tridimensionale dei manufatti è stato sufficiente verificare che i modelli high-poly non presentassero fori sulle superfici (è stato imposto quindi che la frontiera del modello non presentasse interruzioni) e procedere alla conversione nel formato adeguato alle operazioni di stampa 3D.

In quello in cui, invece, i modelli sono stati impiegati per applicazioni AR (realtà aumentata) - MR (realtà mista) sono stati necessari ulteriori passaggi. In primo luogo, si è proceduto ad una decimazione delle mesh e a una loro ottimizzazione fino ad ottenere dei modelli medium-poly. Allo scopo di garantire la loro corretta fruizione all'interno di programmi di visualizzazione real-time è stato ritenuto opportuno ridurre ulteriormente il numero dei poligoni attraverso un processo di retopology (creazione di maglie isotrope) realizzato con il software Instant Mesh al fine di ottenere un modello quad-dominant low-poly [I0] (fig. 8). Questa operazione ha comportato una semplificazione del livello di dettaglio della mesh originale che è stato successivamente reintrodotto tramite l'utilizzo delle normal map e delle diffuse color map desunte a seguito della parametrizzazione [l I] dei modelli e dei processi di baking delle informazioni, realizzati a partire dai modelli high-poly mediante il programma Blender 3D.

Grazie a questa procedura è stato possibile ottenere un modello controllabile in ogni sua parte, sulle cui superfici sono stati applicati, sempre tramite il software Blender 3D, i fotopiani ottenuti da Agisoft Metashape e post prodotti in Adobe Photoshop.

Completate le operazioni sui modelli è stato possibile, ad esempio, importarli in un motore grafico che consente lo sviluppo di contenuti interattivi: nel progetto di ricerca in questione è stato utilizzato Unity della Unity Technologies integrato con il plug-in Vuforia Augmented Reality.

La realtà aumentata, a differenza di altre forme di fruizione 3D dei contenuti digitali, permette di avere sempre uno stretto rapporto con il reale al quale vengono aggiunte una serie di informazioni legate ai modelli 3D.

Nella specifica applicazione qui illustrata è possibile distinguere due diverse modalità per accedere ai contenuti digitali: marker based o markerless based. Nel primo caso viene fornito un target bidimensionale o tridimensionale che consente al device di leggere le informazioni reali e di correlarle a dei dati virtuali. II sistema markerless based ricorre invece al GPS (nel caso della Location Based AR) o a delle immagini (Markerless AR) per attivare gli stessi dati [Alvaro-Tordesillas 2019, pp. 7I, 72].

Per il Centro di Interpretazione della bassa Valdisieve si è ritenuto opportuno utilizzare la tecnologia marker based: tramite l'utilizzo di device sul quale è stata preliminarmente istallata una App (fig. 9) è possibile, inquadrando mappe, fotografie storiche, documenti o modelli fisici, visualizzare i corrispondenti modelli digitali interrogabili in ogni loro aspetto, permettendo così una fruizione smart delle informazioni desunte attraverso le analisi storiche, archeologiche e morfo-metriche. (A.M.). 


\section{Note}

[I] 'Ghibertiana' è un progetto universitario nato dalla collaborazione tra il Dipartimento di Architettura (DIDA) e il Dipartimento di Storia, Archeologia, Geografia, Arte, Spettacolo (SAGAS) di UNIFI. Coordinano il Progetto Alessandro Merlo e Giuseppina Carla Romby; il Comitato Scientifico è formato, oltre che da questi ultimi, da Paolo Clini e dai responsabili di ciascuna delle sale espositive (Dora Liscia Bemporad, Paolo Nanni, Francesco Salvestrini, Guido Vannini con Chiara Molducci). Per maggiori informazioni sul Progetto cfr. <www.ghibertiana.it> (consultato il 10 maggio 202I).

[2] Termine con il quale si suole indicare storicamente la parte del territorio lambito a Nord dall'omonimo corso d'acqua, a Ovest da un tratto del Valdarno inferiore, a Sud dalla dorsale del Pratomagno che lo divide dal Casentino e, infine, a Est dal Mugello e che oggi comprende i comuni di Pelago, Pontassieve, Londa, Reggello, Rufina e San Godenzo. Gli insediamenti si trovano all'interno di un paesaggio molto vario che passa dall'alta collina, alla mezzacosta, fino al fondovalle.

[3] Strumentazione utilizzata: scanner laser Z+F 5006h, drone DJl Mavic mini 2, macchina fotografica Nikon D3200 con obbiettivo Nikon 18-55. Sono state effettuate 24 scansioni e 482 fotografie, dalle quali è stata ottenuta una nuvola densa di 2,3 $\times 10^{8}$ punti.

[4] Strumentazione utilizzata: scanner laser Z+F 5006h, drone DJl Mavic mini 2, macchina fotografica Nikon D3200 con obbiettivo Nikon 18-55. Sono state effettuate I I 4 scansioni e 3889 fotografie, dalle quali è stata ottenuta una nuvola densa di $1,1 \times 10^{9}$ punti.

[5] Strumentazione utilizzata: scanner laser Z+F 5006h, drone DJl Mavic mini 2, macchina fotografica Nikon D3200 con obbiettivo Nikon 18-55. Sono state effettuate 45 scansioni e 953 fotografie, dalle quali è stata ottenuta una nuvola densa di 4,2 $\times 10^{8}$ punti.

[6] II rilievo strumentale è stato ugualmente condotto nonostante le difficoltà di accesso. Strumentazione utilizzata: scanner laser Z+F 5006h, drone DJI Mavic mini 2, macchina fotografica Nikon D3200 con obbiettivo Nikon I 8-55. Sono state effettuate 17 scansioni e 257 fotografie, dalle quali è stata ottenuta una nuvola densa di 1,6 $\times 10^{8}$ punti.

[7] Strumentazione utilizzata: scanner laser Z+F 5006h, drone DJI Mavic mini 2, macchina fotografica Nikon D3200 con obbiettivo Nikon 18-55. Sono state effettuate 48 scansioni e 1699 fotografie, dalle quali è stata ottenuta una nuvola densa di $4,5 \times 10^{8}$ punti.

[8] Archeologia del territorio (del paesaggio e ambientale) integrata con procedure di analisi delle stratigrafie murarie su base archeo-informatica e che prevede lo scavo solo in casi specifici.

[9] Correzione di geometrie non-manifold, clusters, dangling faces, e poligoni sovrapposti.

[ I 0] L'operazione è stata effettuata su Instant Meshes per testare le potenzialità del software gratuito e ottenere automaticamente maglie isotrope quadrate. L'operazione di retopology avrebbe potuto essere effettuata sul software Foundry Luxology Modo che avrebbe consentito una suddivisione semantica degli elementi (non è escluso che nel proseguo del lavoro si preferisca alternare i procedimenti sulla base delle specifiche del manufatto).

[I I] La parametrizzazione della texture in Blender 3D fornisce in genere risultati migliori rispetto a quelli che sarebbe stato possibile ottenere esportando quella ottenuta direttamente da Agisoft Metashape.

\section{Riferimenti bibliografici}

Alvaro-Tordesillas A., Crespo-Aller S., Barba S. (2019). Artalive: an android application for augmented reality without markers, based on anamorphic images. Atti del convegno Avila, Spagna, I-5 settembre 20 I 9. In ISPRS, vol. XLII-2M I 5, pp. 7I-76.

Apollonio F., Ballabeni M., Gaiani M. (20।4). Colour enhanced pipelines for reality-based 3D modelling of onsite medium sized archaeological artefacts. In Virtual Archaeology Review, n.5( I 0), pp. 59-76.

Becattini M., Granchi A. ( 1985). Alto Mugello, Mugello, Val di Sieve: itinerario nel patrimonio storico-artistico. Firenze: Giorgi \& Gambi.

Bianchini C. (20I4). Survey, modeling, interpretation as multidisciplinary components of a knowledge system. In SCIRES-IT, vol. 4, issue I, pp. 15-24.

Bicchierai M. (2005). La signoria dei conti Guidi in Valdarno. Osservazioni ed ipotesi. In Pinto G., Pirillo P. (a cura di). Lontano dalle città. II Valdarno di Sopra nei secoli XII-XIII. Atti del Convegno. Figline Valdarno - Montevarchi, 9-II novembre 200 I, pp. 83- I 16. Roma:Viella.

Buonamici F. et al. (2017). Reverse engineering modelling methods and tools: a survey. In Computer-Aided Design and Applications, n. 15, pp. I-22.

Cherubini G. (2009). Paesaggi, genti, poteri, economia del Casentino negli ultimi secoli del Medioevo. In Rivista di storia dell'agricoltura, n. I, vol. 49, pp. 35-57.

Clini P. (a cura di). (201 I). Documentare l'architettura storica: analisi, rilievo e progetto. Roma: Aracne Editrice.

Cohen J. et al. (1996). Simplification Envelopes. In SIGGRAPH'96. Atti del convegno. New York, NY, USA, agosto I996, pp. I I9128. New York: ACM Press.

Cohen J., Olano M., Manocha D. (1998). Appearence-preserving simplification. In SIGGRAPH'98. Atti del convegno. New York, NY, USA, luglio 1998, pp. I 15- I22. New York: ACM Press.

Gabellone F. (2012). La trasparenza scientifica in archeologia virtuale: una lettura critica al principio n. 7 della Carta di Siviglia. In SCIRES-IT, vol. 2, issue 2, pp. 99-I23.

Merlo A. et al. (20I5). The fortified settlement of Bivignano. Computer graphic tools in analysis and its representation. In CHNT19. Atti del convegno. Vienna, 3-5 novembre 2014. 
Minto S. (20I3). PointCloud2Publish. Visualizzazione e condivisione online di modelli 3D. Tesi del master Open Téchne, tutor F. Remondino. Fondazione Bruno Kessler.

Morozzi G. (2009). Relazione sui danni sofferti a causa della guerra dal patrimonio artistico monumentale di Firenze (1946). In Paolini C. (a cura di). Quaderno del servizio educativo, n. 26. Firenze: Polistampa.

Pan R. et al. (2017). Normals and texture fusion for enhancing orthogonal projections of 3D models. In Journal of Cultural Heritage, vol. 23, pp. 33-39.

Rauty N. (2003). Documenti per la storia dei conti Guidi in Toscana. Le origini e i primi secoli 887- I I 64. Firenze: Olschki editore.

Remondino F. (2004). From point cloud to surface: modelling and visualization problem. WG V/6. Atti del convegno. Tarasp-Vulpera, Svizzera, 24-28 febbraio 2003. International. In ISPRS, vol. XXXIV, pp. 34, 35.

Salvestrini F. (2009). I conti Guidi e il monachesimo vallombrosano. In Canaccini F. (a cura di). La lunga storia di una stirpe comitale. I conti Guidi tra Romagna e Toscana. Atti del convegno. Modigliana - Poppi, 28-3I agosto 2003, pp. 29l-3 I5. Poppi: Olschki Editore.

Vannini G., Molducci C. (2009). I castelli dei Guidi fra Romagna e Toscana: i casi di Modigliana e Romena; un progetto di archeologia territoriale. In Canaccini F. (a cura di). La lunga storia di una stirpe comitale. I conti Guidi tra Romagna e Toscana. Atti del convegno. Modigliana - Poppi, 28-3I agosto 2003, pp. 177-2 10. Poppi: Olschki Editore.

Verhoeven G. (2017). Computer graphics meets image fusion: the power of texture baking to simultaneously visualise 3D surface features and colour. In ISPRS. Atti del convegno. Ottawa, Canada, 28 agosto-I settembre 20 I 7. vol. IV-2W2, pp. 295-302.

\section{Autori}

Giulia Lazzari, Università degli Studi di Firenze, giulia.lazzari@unifi.it

Alessandro Manghi, Università degli Studi di Firenze, alessandro.manghi@unifi.it

Per citare questo capitolo: Lazzari Giulia, Manghi Alessandro (2021). Modelli interpretativi per la fruizione digitale delle architetture widinghe/ Interpretative Models for the Digital Fruition of Widinghe Architectures. In Arena A., Arena M., Mediati D., Raffa P. (a cura di). Connettere. Un disegno per annodare e tessere. Linguaggi Distanze Tecnologie. Atti del $42^{\circ}$ Convegno Internazionale dei Docenti delle Discipline della Rappresentazione/ Connecting. Drawing for weaving relationship. Languages Distances Technologies. Proceedings of the 42th International Conference of Representation Disciplines Teachers. Milano: FrancoAngeli, pp. 2437-2454. 


\title{
Interpretative Models for the Digital Fruition of Widinghe Architectures
}

\author{
Giulia Lazzari \\ Alessandro Manghi
}

\section{Abstract}

During the $11^{\text {th }}$ and $12^{\text {th }}$ centuries the Valdisieve fell under the dominion of the powerful family of Conti Guidi, already lords of Arezzo's area and later of Empoli's area. They had fully understood the strategic importance of this land, located on the border of the Florentine countryside, which allowed them to control the expansionist aims of the rich Florentine bourgeoisie [Vannini 2009, p. 208].

The presence of Guidi's family was ensured by the numerous castles, walled villages and religious buildings under their direct control or that of their affiliates. Their hegemony over these lands continued until the $14^{\text {th }}$ century, when Florence gradually regained possession of the border territories; in this context the Valdisieve, which was of no particular interest to the central power, began a slow decline that affected its architectural heritage with inclemency [Cherubini 2009, p. 45].

Today there are numerous testimonies of that period and the belt of castles and churches built around Florence is still clearly visible (fig. I).

The contribution intends to illustrate the first results of a research project on these artefacts erected in the lower Valdisieve and to create a database containing the results of the studies conducted on them, starting with the geometric-dimensional ones.

The digital copies of these buildings, taken from today's range-based and image-based surveying systems, aim not only at documenting the morphometric and chromatic data, but also at conveying the results of the research itself in new forms that are closer to the expectations of both the general public and the experts. (G.L.).

Keywords

Ghibertiana, Conti Guidi, digital survey, archaeology, augmented reality.

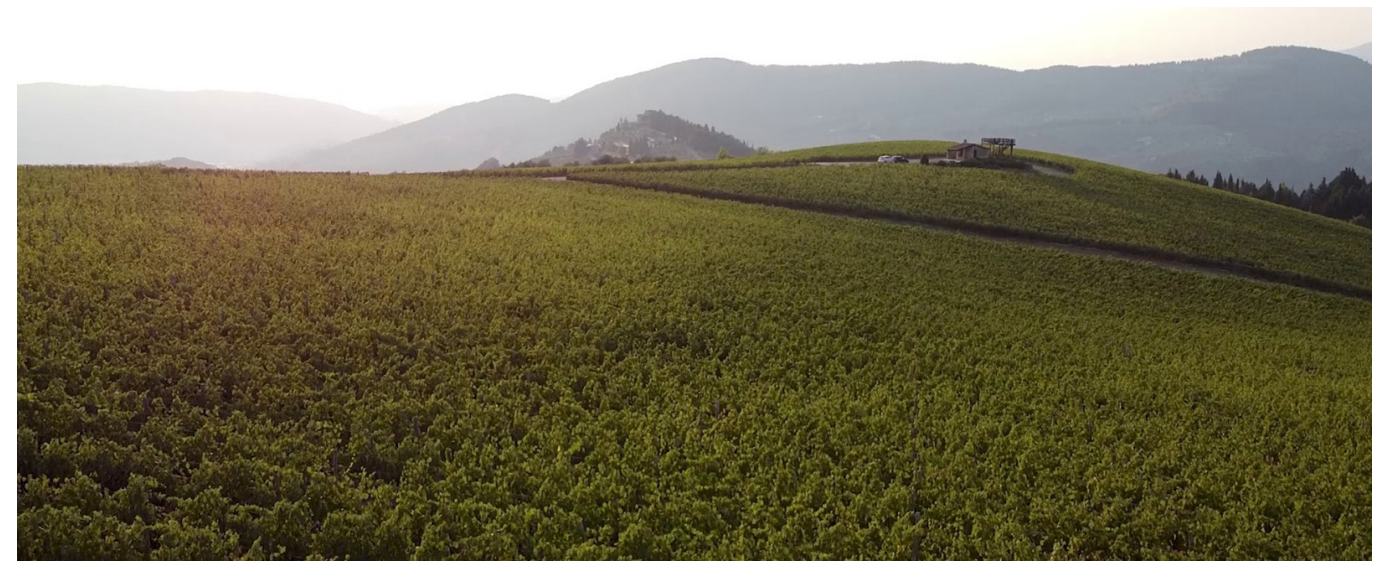




\section{Introduction}

This research is part of a complex, interdisciplinary and multi-scalar project, called 'Ghibertiana' [I]. It aims at enhancing the link between the cultural heritage of the lower Valdsieve [2] and the opera of Lorenzo Ghiberti (Pelago 1378, Florence 1455), who was born and made his fortune in this area.

The project envisages the creation of the Documentation Centre on Lorenzo Ghiberti, in which all the information on the artist and his works will be collected in dematerialised form, allowing scholars to have a dedicated place for researches on the artist, and the Interpretation Centre on the lower Valdisieve, where it will be possible to acquire the keys to decode the most interesting places in this part of the territory (Le terre del Ghiberti) in the correct historical perspective.

There are five main axes that qualify the exhibition path of this Centre: the landscape of vines and olive trees / the castles of the Conti Guidi / the forest of Vallombrosa / the working of noble metals and Ghiberti's workshop / the doors of Paradise in the Baptistery of Florence.

There is no doubt that the immense patrimony inherited by the Conti Guidi, despite the transformations that have taken place over almost two centuries, characterised the landscape of the lower Valdisieve in Ghiberti's time as it does today.

The renewed interest in these structures, some of which have survived for the most part intact, while others can only be documented through their fragments, has prompted the multidisciplinary group involved in the research -which includes historians, art historians, architects and archaeologists- to identify the castle of Nipozzano and that of San Leoli-

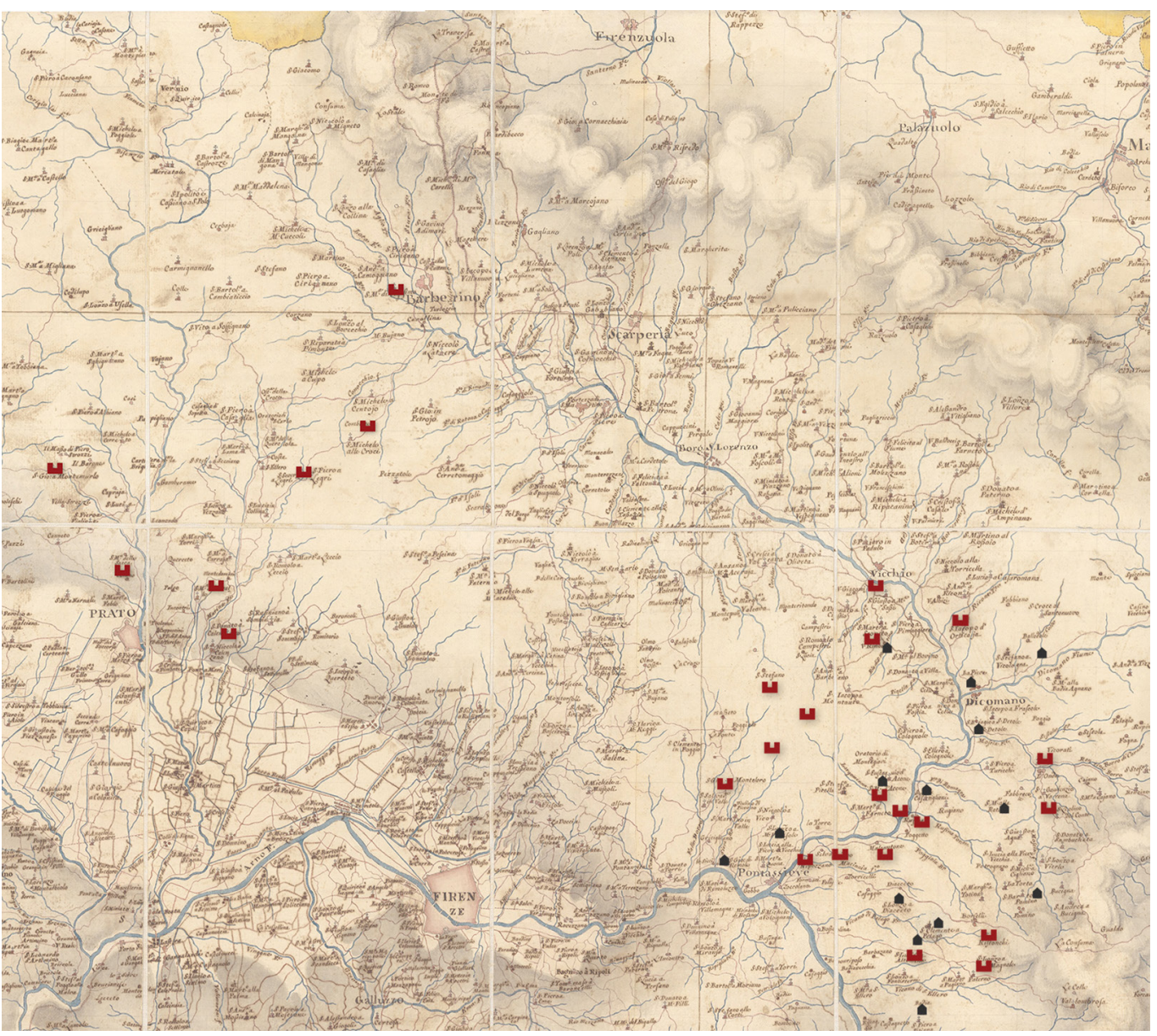


no, the church of Santa Maria a Ferrano, the remains of the church of San Gervasio and that of Magnale as the sites for the first historiographic, archaeological and architectural studies. (G.L.).

\section{Morphometric documentation of widinghe architectures}

Among the first operations carried out by the working group were those aimed at defining the morphometry of the assets under investigation.

The artefact studied can be classified into two distinct categories: the first includes buildings in a deplorable state of decay, made even more evident by the presence of 'long-lasting' infesting vegetation (San Gervasio, San Leolino and parts of Nipozzano), but which retain numerous original elements (generally indicative of early abandonment); the second includes those buildings which, although they are in a good state of preservation, have been subjected to numerous restorations so as to make it difficult to identify the elements attributable to the period in which they were erected (Magnale, Ferrano and numerous buildings in Nipozzano).

As is generally the case in the study of historical architecture, the morphometric survey is called upon to fulfil at least two purposes: to document geometric data that are progressively being lost and to deduce the data necessary to be able to define the changes that have occurred over time [Clini 20I I, p. 9].

The only part that remains of the castle of San Leolino (fig. 2), a fortification dating back to I I 64, is a tower with a roughly triangular cross-section and rounded corners, in which a large portal opens, set on a rocky wall that rises above the territory below; the underground cistern, accessible by a staircase, is still in good condition. The forest in which it is located, together with the collapse of all the horizontal structures and a large part of the vertical ones, almost entirely hides what remains of the building, making the acquisition and the subsequent restitution of data particularly difficult [3].

The castle of Nipozzano (fig. 3) is undoubtedly one of the complexes in the best state of conservation as it has undergone numerous restoration interventions over time. The building stands among the vineyards of the Frescobaldi family, dominating the Sieve valley with an imposing keep and two minor towers, flanked by a small village and the church of San Nicolò, dating back to the $16^{\text {th }}$ century; that one, like the castle, was largely rebuilt following damage sustained during the Second World War. The North-West area, now in a state of ruins, has some portions of masonry dating back to the beginning of the $\mathrm{I}^{\text {th }}$ century. Apart from this area, for which the difficulties are like those en-

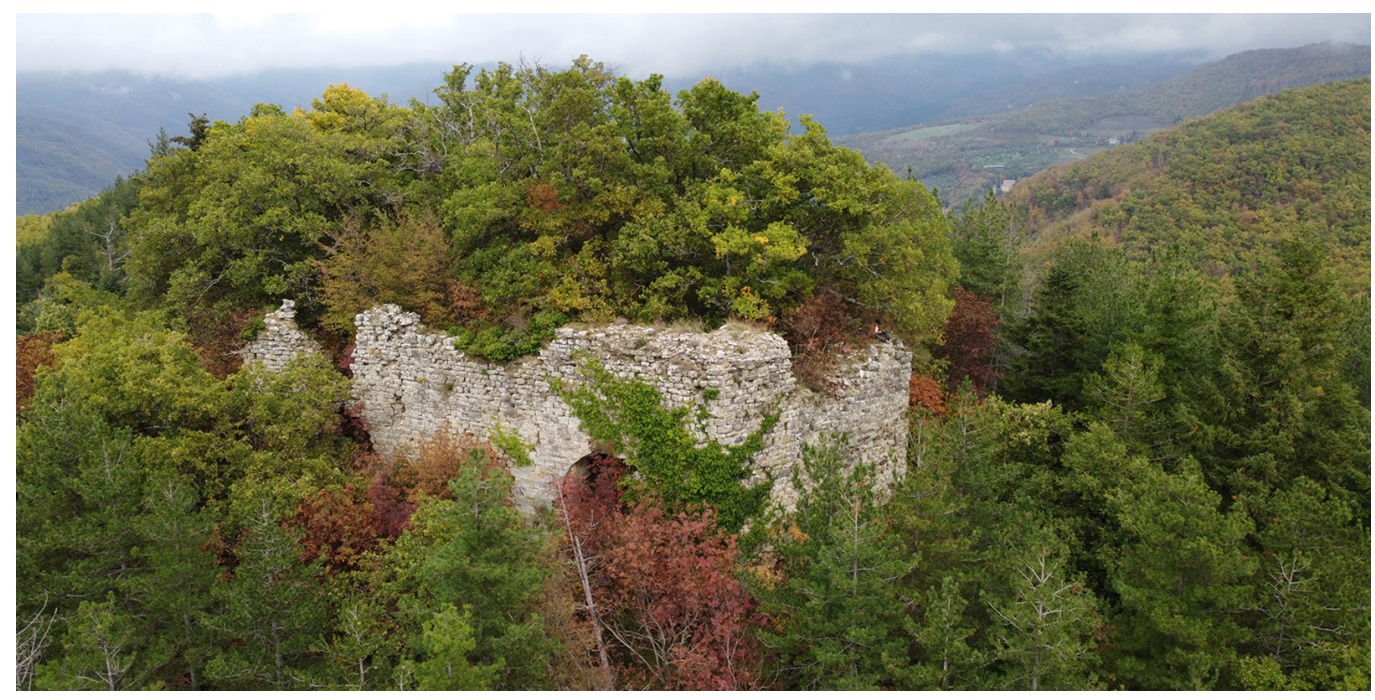


Fig. 3. The castle of Nipozzano: in the foreground, the church of San Niccolò on the left and the keep on the right (authors' photo).

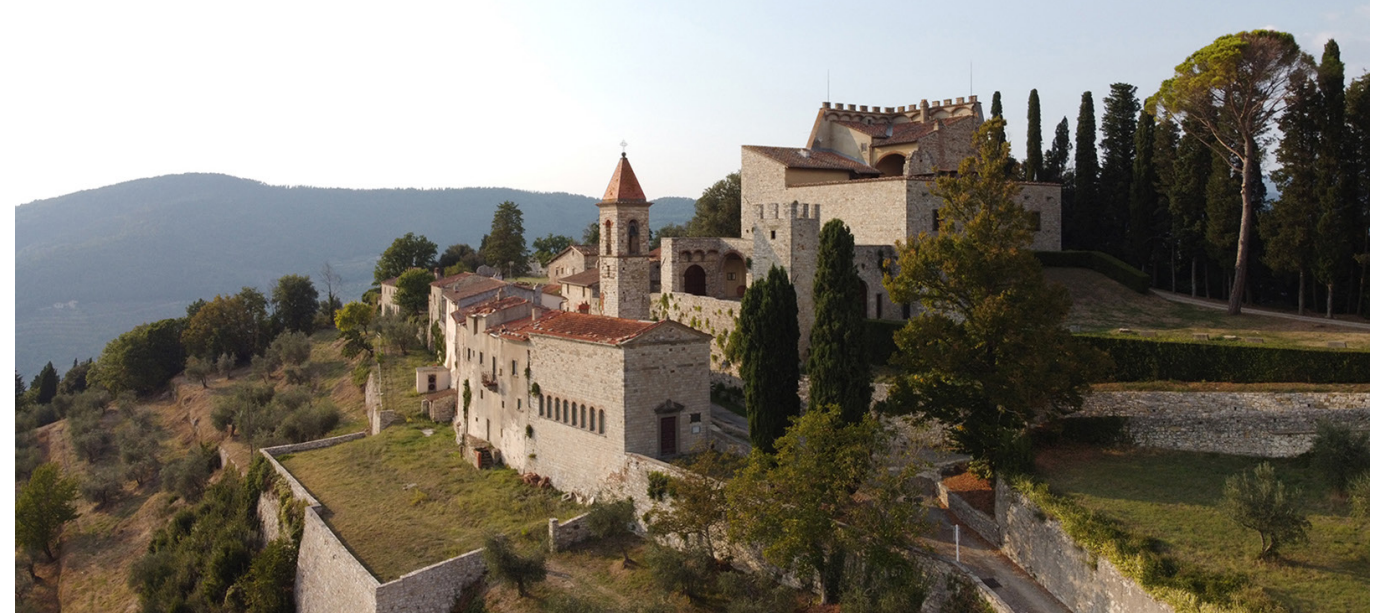

countered in San Leolino, the survey operations in the remaining areas did not present any problems and were carried out using both laser scanning and aerial and terrestrial photogrammetry [4].

The Magnale castle, whose toponym denotes Etruscan origin, is mentioned in the acts relating to the nearby Abbey of Vallombrosa from I I03. The present appearance of the complex (fig. 4) is the result of the heavy modifications made in the mid- $18^{\text {th }}$ century, the extent of which can be seen by observing the ashlars near to the entrance of the church, the side front on which the cemetery stands and the walls supporting the complex towards the valley. In this case, the survey [5] documented artefacts that are still in use and whose state of maintenance can be considered more than good; this made it possible to obtain a complete morphological and chromatic description of the various fronts and the interior of the church.

Completely different is the case of the church of San Gervasio (fig. 5) dating back to I I 64; from the few remains it is possible to infer little more than the ground plan. The vegetation that almost entirely covers the structure has made survey [6] operations extremely difficult. Finally, the last complex examined is the church of Santa Maria a Ferrano and the neighbouring village (fig. 6); both have been restored in very recent times and are therefore in

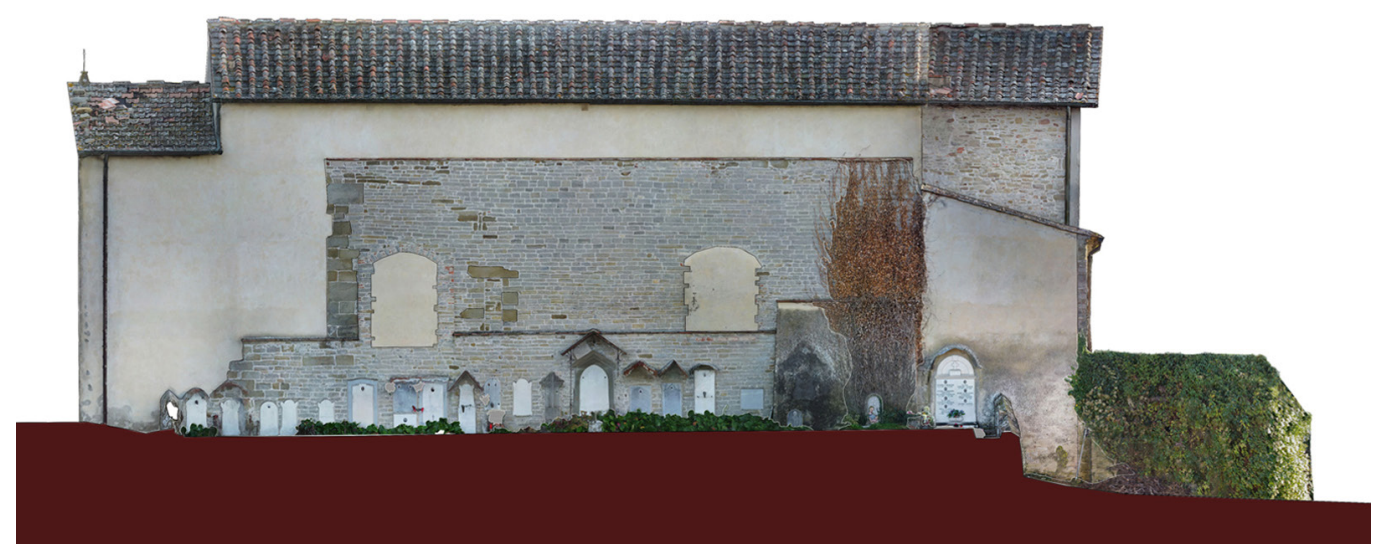






excellent condition. At first glance, the walls seem to present some elements dating back to the time of construction; the data [7] acquired, and subsequent restorations will allow to further investigate the initial hypotheses. (A.M.).

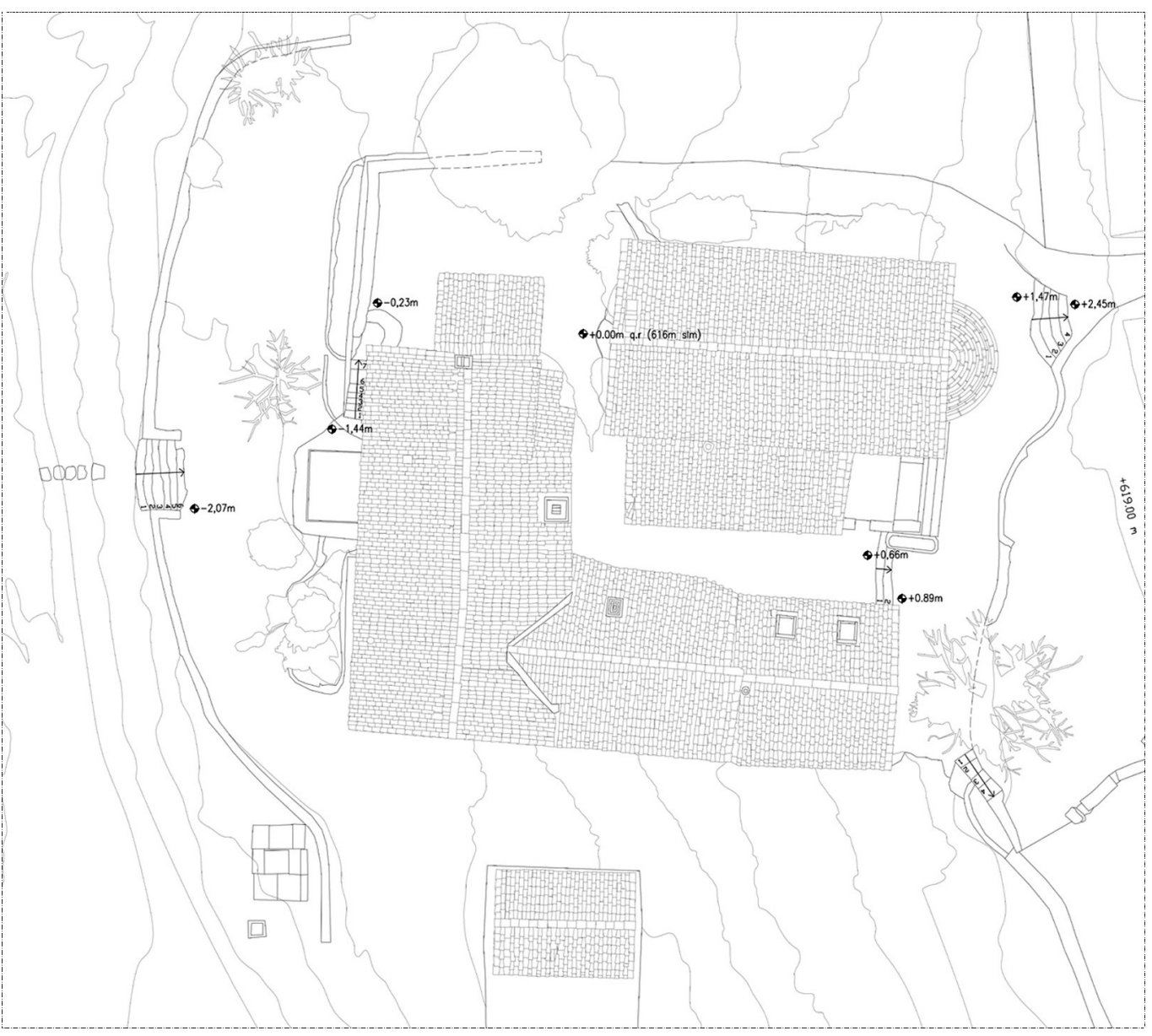




\section{Reading the survey}

Although in the 4.0 era the traditional two-dimensional drawings may seem obsolete, it is certain that plans, sections, and elevations, as well as orthophotos, are still the essential starting point for a thorough investigation of an artefact [Bianchini 20 I4, pp. I5, I6].

In this research, the two-dimensional drawings allowed not only to define shapes, geometries and dimensions of the investigated architectures, but were also indispensable, for example, for the analysis of the elevations (subdivision in Masonry Stratigraphic Units and recognition of Upstanding Building) according to the indications of non-invasive archaeology [8].

The masonry of historic buildings is in fact a palimpsest in which it is possible to trace the interventions of 'construction' (by man) or 'destruction' (by both man and nature), which, when correctly interpreted, make it possible not only to identify the mutual relationships between the different parts of a building, but above all to hypothesise a chronological sequence of the events that have taken place over the centuries.

In this specific case, the chromatic data, deduced through the well-known digital photogrammetry procedures and applied on the elevations, made it possible to recognise and represent the different construction materials, the construction techniques used and the possible presence of decorations or marks left by the workers (fig. 7). (G.L.).

Fig. 7. One of the elevations of the settlement that flanks the keep of Nipozzano (authors' processing).

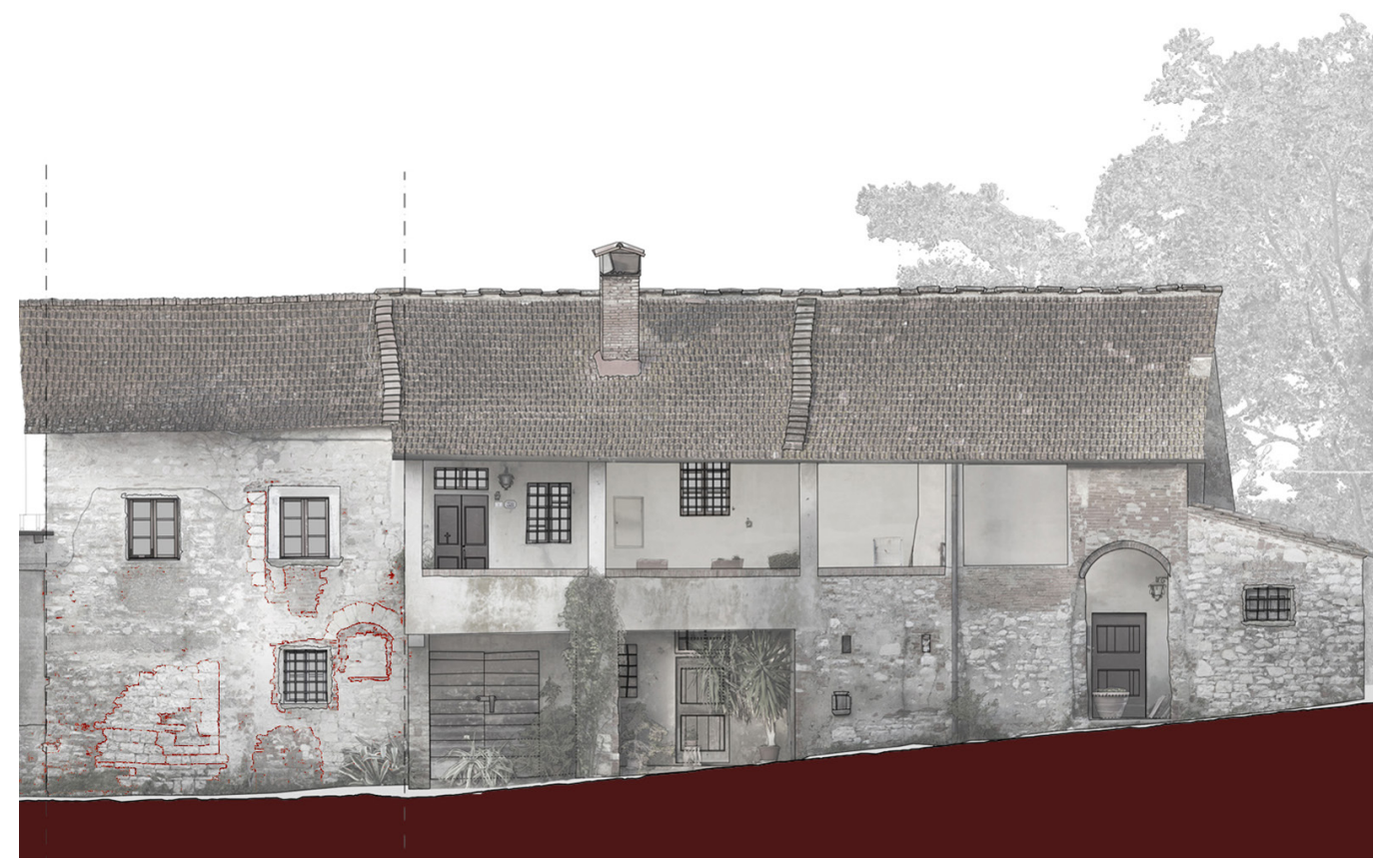

\section{Digital twin and ICT in the museum experience}

For the purposes envisaged within the new Interpretation Centre of the lower Valdisieve, such as 3D reconstructions of the original configurations of the artefacts, the realisation of three-dimensional prints or the visualisation on digital copies of the analyses on the walls, the mesh models extracted from the Agisoft Metashape software underwent refinement and optimisation procedures.

Once the problems related to the mesh geometries were solved within the 3D Systems Geomagic Design X software [9], each model was imported into the Blender 3D software where two workflows could be defined according to the needs of the final output [Minto 20|3, pp. 7, 8]. 
Fig. 8. Passage from the unordered triangular mesh of the mediumpoly model to the quaddominant mesh of the low-poly model through the retopology process.

Fig. 9. Scheme of the operation of the augmented reality App developed with Unity and Vuforia.
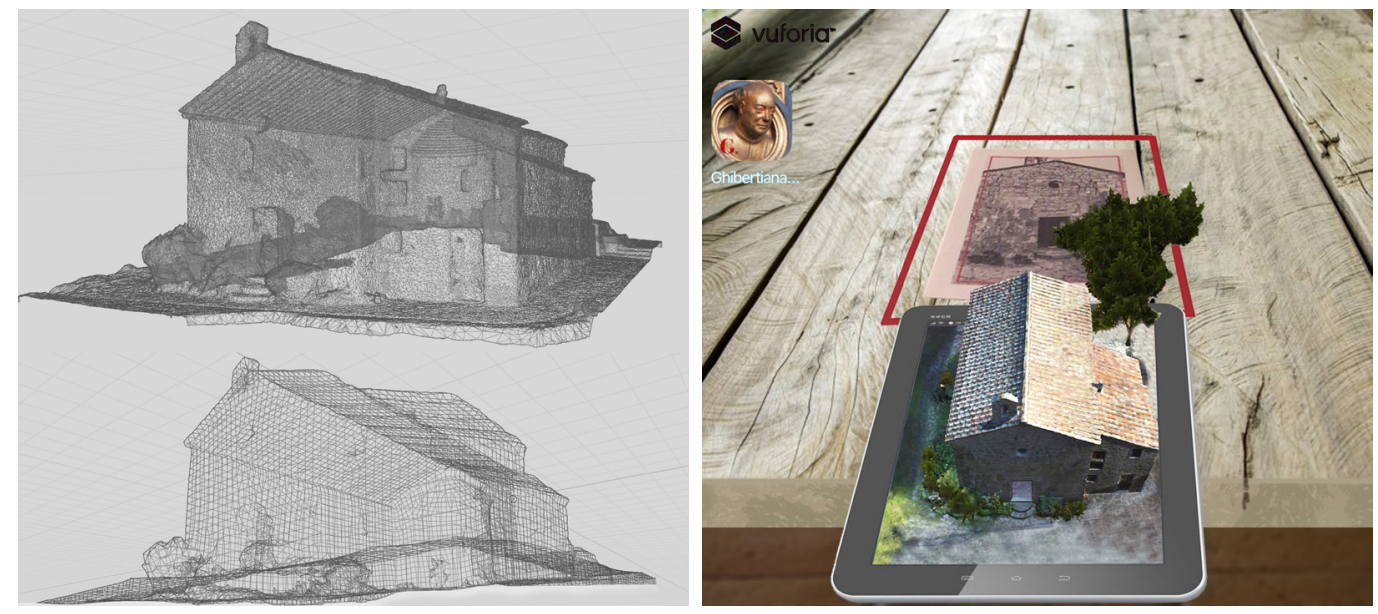

In the case of 3D printing of the artefacts, it was sufficient to check that the high-poly models did not have any holes on the surfaces (it was therefore required that the model border did not present any interruptions) and to proceed with the conversion into the appropriate format for 3D printing operations.

When the models were used for AR (augmented reality) or MR (mixed reality) applications, further steps were required. First, the meshes were decimated and optimised to obtain medium-poly models. In order to guarantee their correct use within real-time visualisation programmes, it was considered appropriate to further reduce the number of polygons through a process of retopology (isotropic meshes created) carried out with Instant Mesh software in order to obtain a quad-dominant low-poly model [I0]. This operation entailed a simplification of the level of detail of the original mesh, which was subsequently reintroduced through the use of normal maps and diffuse colour maps obtained after the parameterisation [ $\mathrm{II}$ ] of the models and the information baking processes, carried out from the high-poly models using the Blender 3D software.

Thanks to this procedure, it was possible to obtain a model that could be controlled in all its parts, on the surfaces of which the ortho-photo obtained by Agisoft Metashape and post-produced in Adobe Photoshop were applied, again using the Blender 3D software.

Once the operations on the models were completed, it was possible, for example, to import them into a graphic engine allowing the development of interactive contents: in this research project, Unity by Unity Technologies was used, integrated with the Vuforia Augmented Reality plug-in (fig.8).

Augmented reality, unlike other forms of 3D enjoyment of digital content, allows a close relationship with reality to which a series of information linked to 3D models is added.

In this specific application it is possible to distinguish two different ways to access digital contents: marker based or marker-less based. In the first case, a two-dimensional or three-dimensional target is provided, and it allows the device to read the real information and to correlate it with virtual data. The marker-less based system instead uses GPS (in the case of Location Based AR) or images (Marker-less AR) to activate the same data [Alvaro-Tordesillas 2019, pp. 71, 72].

For the Interpretation Centre of the lower Valdisieve it was deemed appropriate to use marker-based technology: using a device on which an App has been preliminarily installed (fig. 9) it is possible, by framing maps, historical photographs, documents or physical models, to view the corresponding digital models that can be interrogated in all their aspects, thus allowing a smart use of the information deduced through historical, archaeological and morphometric analysis. (A.M.). 


\section{Note}

[I] 'Ghibertiana' is a university project born from the collaboration between the Department of Architecture (DIDA) and the Department of History, Archaeology, Geography, Art, Entertainment (SAGAS) of the University of Florence. The Project is coordinated by Alessandro Merlo and Giuseppina Carla Romby; the Scientific Committee is formed, in addition to the latter by Paolo Clini and the heads of each of the exhibition halls (Dora Liscia Bemporad, Paolo Nanni, Francesco Salvestini, Guido Vannini with Chiara Molducci). For more information on the Project see <www.ghibertiana.it.> (accessed 2021, May I0).

[2] Historically, this term is used to indicate the part of the territory bordered to the North by the Sieve river, to the West by a part of the Lower Valdarno, to the South by the Pratomagno ridge that divides it from Casentino and, finally, to the East by Mugello, and which today includes the municipalities of Pelago, Pontassieve, Londa, Reggello, Rufina and San Godenzo. The settlements are located within a very varied landscape that goes from the high hills, to the hillside, to the valley floor.

[3] Instrumentation used: Z+F 5006h laser scanner, DJI Mavic mini 2 drone, Nikon D3200 camera with Nikon I8-55 lens. 24 scans and 482 photographs were taken, from which a dense cloud of $2.3 \times 10^{8}$ points was obtained.

[4] Instrumentation used: Z+F 5006h laser scanner, DJI Mavic mini 2 drone, Nikon D3200 camera with Nikon I8-55 lens. I I4 scans and 3889 photographs were taken, from which a dense cloud of $1.1 \times 10^{9}$ points was obtained.

[5] Instrumentation used: Z+F 5006h laser scanner, DJI Mavic mini 2 drone, Nikon D3200 camera with Nikon I8-55 lens. 45 scans and 953 photographs were taken, from which a dense cloud of $4,2 \times 10^{8}$ points was obtained.

[6] The instrumental survey was also carried out despite the difficulties of access. Instrumentation used: Z+F 5006h laser scanner, DJI Mavic mini 2 drone, Nikon D3200 camera with Nikon I8-55 lens. I 7 scans and 257 photographs were taken, from which a dense cloud of $1.6 \times 10^{8}$ points was obtained.

[7] Instrumentation used: Z+F 5006h laser scanner, DJI Mavic mini 2 drone, Nikon D3200 camera with Nikon I8-55 lens. A total of 48 scans and 1699 photographs were taken, from which a dense cloud of $4.5 \times 10^{8}$ points was obtained.

[8] Archaeology of the territory (landscape and environmental) integrated with procedures for the analysis of wall stratigraphy on an archaeo-informatic basis and involving excavation only in specific cases.

[9] Correction of non-manifold geometries, clusters, dangling faces, and overlapping polygons.

[10] The operation was carried out on Instant Meshes in order to test the potential of the free software and automatically obtain square isotropic meshes. The re-topology operation could have been carried out on the Foundry Luxology Modo software, which would have allowed a semantic subdivision of the elements (it is not excluded that in the continuation of the work the procedures will be alternated on the basis of the specifications of the artefact).

$[\mathrm{II}]$ The parameterisation of the texture in Blender 3D generally gives better results than if the texture had been exported directly from Agisoft Metashape.

\section{Riferimenti bibliografici}

Alvaro-Tordesillas A., Crespo-Aller S., Barba S. (2019). Artalive: an android application for augmented reality without markers, based on anamorphic images. Atti del convegno Avila, Spagna, I-5 settembre 20 I 9. In ISPRS, vol. XLII-2/W I5, pp. 7I-76.

Apollonio F., Ballabeni M., Gaiani M. (20।4). Colour enhanced pipelines for reality-based 3D modelling of onsite medium sized archaeological artefacts. In Virtual Archaeology Review, n.5( I0), pp. 59-76

Becattini M., Granchi A. ( 1985). Alto Mugello, Mugello, Val di Sieve: itinerario nel patrimonio storico-artistico. Firenze: Giorgi \& Gambi.

Bianchini C. (20I4). Survey, modeling, interpretation as multidisciplinary components of a knowledge system. In SCIRES-IT, vol. 4, issue I, pp. 15-24.

Bicchierai M. (2005). La signoria dei conti Guidi in Valdarno. Osservazioni ed ipotesi. In Pinto G., Pirillo P. (a cura di). Lontano dalle città. II Valdarno di Sopra nei secoli XII-XIII. Atti del Convegno. Figline Valdarno - Montevarchi, 9-I I novembre 200 I, pp. 83- I 16. Roma:Viella.

Buonamici F. et al. (2017). Reverse engineering modelling methods and tools: a survey. In Computer-Aided Design and Applications, n. I5, pp. I-22.

Cherubini G. (2009). Paesaggi, genti, poteri, economia del Casentino negli ultimi secoli del Medioevo. In Rivista di storia dell'agricoltura, n. I, vol. 49, pp. 35-57.

Clini P. (a cura di). (20I I). Documentare l'architettura storica: analisi, rilievo e progetto. Roma: Aracne Editrice.

Cohen J. et al. (1996). Simplification Envelopes. In SIGGRAPH'96. Atti del convegno. New York, NY, USA, agosto 1996, pp. I I9128. New York: ACM Press.

Cohen J., Olano M., Manocha D. (1998). Appearence-preserving simplification. In SIGGRAPH'98. Atti del convegno. New York, NY, USA, luglio 1998, pp. I 15-122. New York: ACM Press.

Gabellone F. (2012). La trasparenza scientifica in archeologia virtuale: una lettura critica al principio n. 7 della Carta di Siviglia. In SCIRES-IT, vol. 2, issue 2, pp. 99-123.

Merlo A. et al. (2015). The fortified settlement of Bivignano. Computer graphic tools in analysis and its representation. In CHNT19. Atti del convegno. Vienna, 3-5 novembre 2014.

Minto S. (20I3). PointCloud2Publish. Visualizzazione e condivisione online di modelli 3D. Tesi del master Open Téchne, tutor F. Remondino. Fondazione Bruno Kessler. 
Morozzi G. (2009). Relazione sui danni sofferti a causa della guerra dal patrimonio artistico monumentale di Firenze (1946). In Paolini C. (a cura di). Quaderno del servizio educativo, n. 26. Firenze: Polistampa.

Pan R. et al. (2017). Normals and texture fusion for enhancing orthogonal projections of 3D models. In Journal of Cultural Heritage, vol. 23, pp. 33-39.

Rauty N. (2003). Documenti per la storia dei conti Guidi in Toscana. Le origini e i primi secoli 887-I I 64. Firenze: Olschki editore.

Remondino F. (2004). From point cloud to surface: modelling and visualization problem.WGV/6. Atti del convegno.Tarasp-Vulpera, Svizzera, 24-28 febbraio 2003. International. In ISPRS, vol. XXXIV, pp. 34, 35.

Salvestrini F. (2009). I conti Guidi e il monachesimo vallombrosano. In Canaccini F. (a cura di). La lunga storia di una stirpe comitale. I conti Guidi tra Romagna e Toscana. Atti del convegno. Modigliana - Poppi, 28-3I agosto 2003, pp. 29I-3 I5. Poppi: Olschki Editore.

Vannini G., Molducci C. (2009). I castelli dei Guidi fra Romagna eToscana: i casi di Modigliana e Romena; un progetto di archeologia territoriale. In Canaccini F. (a cura di). La lunga storia di una stirpe comitale. I conti Guidi tra Romagna e Toscana. Atti de convegno. Modigliana - Poppi, 28-3I agosto 2003, pp. I77-2 I0. Poppi: Olschki Editore.

Verhoeven G. (2017). Computer graphics meets image fusion: the power of texture baking to simultaneously visualise 3D surface features and colour. In ISPRS. Atti del convegno. Ottawa, Canada, 28 agosto- I settembre 20 I 7. vol. IV-2W2, pp. 295-302.

\section{Authors}

Giulia Lazzari, Università degli Studi di Firenze, giulia.lazzari@unifi.it

Alessandro Manghi, Università degli Studi di Firenze, alessandro.manghi@unifi.it

To cite this chapter. Lazzari Giulia, Manghi Alessandro (2021). Modelli interpretativi per la fruizione digitale delle architetture widinghe/Interpretative Models for the Digital Fruition of Widinghe Architectures. In Arena A., Arena M., Mediati D., Raffa P. (a cura di). Connettere. Un disegno per annodare e tessere. Linguaggi Distanze Tecnologie. Atti del $42^{\circ}$ Convegno Internazionale dei Docenti delle Discipline della Rappresentazione/Connecting. Drawing for weaving relationship. Languages Distances Technologies. Proceedings of the 42th International Conference of Representation Disciplines Teachers. Milano: FrancoAngeli, pp. 2437-2454. 